ESUKA - JEFUL 2010, 1 - 1: 5 - 19

\title{
EESTI KEELE TEISE KEELENA UURIMINE TARTU ÜLIKOOLIS - HETKESEIS JA PERSPEKTIIVID
}

\author{
Raili Pool \\ Tartu Ülikool
}

Kokkuvõte. Artikkel annab ülevaate Tartu Ülikoolis valminud eesti keele teise keelena omandamise alastest uurimustest, eesti keele kui teise keele õpetamiseks loodud õppevahenditest ning õppemetoodilistest materjalidest. Teise keele omandamise alal on valminud hulgaliselt üliõpilaste lõputöid, kuid teadusmagistri- ja doktoriväitekirju on kaitstud vaid üksikuid ning uurimissuuna arendamine seisab suures osas alles ees. Eesti keele (võõrkeelena) osakonnas on loodud mitmesuguseid nii traditsioonilisi kui ka interaktiivseid õppevahendeid ning suund on võetud eelkõige veebipõhiste eesti keele õppematerjalide väljatöötamisele. Eesti keele kui teise keele uurimissuuna arendamise väljavaated Tartu Ülikoolis on otseselt seotud sellega, kas onnnestub peale kasvatada valdkonnast huvituvaid noori uurijaid ja moodustada uurimisgrupp.

Märksõnad: teise keele omandamine, veaanalüüs, keeleõppe metoodika, interaktiivsed õppevahendid, eesti keel

\footnotetext{
Abstract. Research at the University of Tartu on Estonian as a second language - present situation and future prospects. The article gives an overview of the studies conducted at the University of Tartu on Estonian as a second language and of the methodology and study aids designed for learning and teaching Estonian. While several BA theses have been defended on the acquisition of Estonian as a second language, there are but few MA theses and only one $\mathrm{PhD}$ thesis on the topic, leaving this research area still largely uncharted. Various traditional and interactive study aids have been designed at the Department of Estonian as a Foreign Language; the aim is to create web-based study aids for learners of Estonian. Future prospects for research at the University of Tartu on Estonian as a second language depend on the relevant units being able to attract young researchers who are interested in the topic and who can form a research team to study it.
} 
Eesti keel teise keelena Tartu Ülikoolis 2

Keywords: second language acquisition, error analysis, methodology, interactive study aids, Estonian

\section{Sissejuhatuseks}

Eesti keele kui teise keele uurimine, õpetamine ja õppemetoodiline töö on Tartu ülikoolis eesti keele (võõrkeelena) osakonna pärusmaa. Põhjaliku ülevaate osakonna kujunemisest, aja jooksul toimunud muutustest, õppe- ja teadustööst ning inimestest saab koguteoses „200 aastat eesti keele ülikooliõpet” ilmunud Birute Klaasi artiklist (Klaas 2003). Siinses kirjutises ei korrata nimetatud ülevaates kirjapandut, vaid keskendutakse eesti keele kui teise keele uurimises tehtule, osakonnas valminud ja teoksil olevatele õppevahenditele ning vaetakse uurimissuuna tulevikuvälja-vaateid.

\section{Eesti keele kui teise keele omandamise uurimine}

Eesti keele kui teise keele omandamise uurimine on Tartu ülikoolis kestnud alles üsna lühikest aega ning see on tihedalt seotud keeleõppega. Seejuures on eesti keele õpetamisel tunduvalt pikem ajalugu (vt Klaas 2003). Eesti keele kui teise keele/võõrkeele õpetamine sai hoo sisse 1990ndate aastate alguse muutunud ühiskondlikes oludes ning sellal tõusis probleem, kuidas ja milliste materjalide alusel keelt õpetada. Küsimus, kuidas keeleõppijad eesti keelt õpivad, mida nad omandavad ja mis jääb pingutustele vaatamata ikkagi täielikult omandamata, on tegelikult tõsisemalt huviorbiiti tõusnud alles käesoleval aastatuhandel. Uurimissuuna uudsust illustreerib ka fakt, et 2003. aastal Emakeele Seltsi aastaraamatus ilmunud mahukas eesti keele uurimise analüüsis pole Tartu ülikoolis tehtud teise keele omandamise alastest töödest olnud nimetada midagi muud peale konverentside „Emakeel ja teised keeled” ettekandekogumike (Hennoste 2003: 234). Võttes arvesse eesti keele õpetamise järjest suurenenud mahtu, on loomulik, et ka keeleomandamise uurimine teenib peamiselt pedagoogilisi eesmärke. Omandamist on uuritud valdavalt suunitlusega, et kui onnestuks kindlaks teha omandamise raskuspunktid, oskaksime paremini õpetada ja efektiivsemaid õppevahendeid luua. 
Pedagoogiline suunitlus ongi põhjuseks, miks teise keele uurimine on praeguseni olnud keeleõppijate vigadest lähtuv ning peamise uurimismeetodina on rakendatud veaanalüüsi, sageli ühendatult õppijate emakeelt ja eesti keelt kui sihtkeelt võrdleva kontrastiivse analüüsiga.

\section{1. Üliõpilaste lõputööd}

Eesti keele õppijate keelevigade analüüs on eesti keele (võõrkeelena) osakonna üliõpilaste hulgas olnud populaarne lõputööde teemavaldkond ning varasema, nelja-aastase bakalaureuseõppe lõputöödena on sel alal valminud üle kahekümne uurimuse. Valdavalt on uuritud vene emakeelega õpilaste või üliõpilaste grammatika-, vähem sõnavaravigu. Kuna lõputöö tegemise aeg on piiratud, on tegemist peamiselt ristlõikeliste uurimustega, mille puhul vaadeldakse õppijate kõnesooritusi ühel kindlal ajahetkel. Pikiuurimusi, milles analüüsitakse samadelt õppijatelt pikema perioodi jooksul kogutud keelenäiteid, on praeguseks tehtud vähe.

Bakalaureusetööd jäävad enamasti käsikirjalisena osakonna raamatukogu riiulile ning nende tulemused on seetõttu teistele alaga tegelejatele raskesti kättesaadavad. Selle probleemi lahendamiseks ning teise keele uurijatele avaldamisvõimaluse pakkumiseks nägi 2005. aastal eesti keele (võõrkeelena) õppetooli toimetiste sarjas trükivalgust artiklikogumik „Teine keel”. Kolm kogumikus sisalduvat artiklit põhinevad üliõpilaste bakalaureusetöödel ning käsitlevad vene emakeelega õppijate keelevigu. Olga Pastuhhova (2005) käsitleb interferentsist põhjustatud süntaksivigu suulises ja kirjalikus õppijakeeles, Maria Ratassepp (2005) verbirektsioonivigu ning Julia Šarapova (2005) mineviku ajavormide kasutamisel tehtud vigu. J. Šarapova uurimus on üks väheseid pikiuurimusi, mis võimaldab rohkem vaadelda omandamise kulgu. Kuigi algselt oli „Teine keel” planeeritud alustama samanimelist väljaandesarja (eeskujuks Helsingi ülikoolis ilmuv sariväljaanne „Kakkoskieli”), pole järgmist osa mitmel põhjusel seni ilmunud.

Üliõpilastöödena valminud uurimustes on käsitletud veel nt teise keele õppijate sõnajärjevigu (Grudkina 2002), objekti- 
Eesti keel teise keelena Tartu Ülikoolis 4

vigu (Orlova 2003), ühildumisvigu (Tšerednikova 2002), modaalverbide kasutamist (Titova 2003), muutumisverbide kasutamist (Vlassova 2002), paronüümide omandamist (Bendi 2004) jm. Seejuures kõnelevad ka lõputööde autorid eesti keelt enamasti teise keelena, mis paratamatult seab uurimuste sisule teatud piirangud ning asetab tööde juhendajatele suure koormuse ja vastutuse - neil kui eesti keelt emakeelena kõnelejatel tuleb tegelikult kogu materjal üle kontrollida. Probleemiks on siin eelkõige teise keele kõnelejatest üliõpilaste suurem nõudlikkus uuritavate õppijate keelekasutuse suhtes: olles ise samuti keeleõppijad, püüavad nad materjali analüüsimisel lähtuda keelereeglitest ja on vahel hinnangutes rangemad kui emakeelekõnelejad ise, kes keeletajust lähtudes aktsepteerivad rohkem leksikaalseid ja grammatilisi paralleelvariante.

Kolmeaastase bakalaureuseõppe lõputööd on eesti keele (võõrkeelena) osakonnas valdavalt referatiivsed ning empiirilisel materjalil põhinevad uurimused jäävad magistriastmesse. Magistritöödes on käsitletud näiteks muukeelsete lasteaialaste eesti keele omandamist (Ljutov 2007), liitsõnade moodustamise oskusega seonduvaid probleeme (Borovkova 2008), emakeelekõnelejate hinnanguid mitte-eestlaste keelevigadele (Savkovitš 2008), eesti keele õppe motivatsiooni venekeelsetes koolides (Borissenko 2009), vene-eesti vahekeele onomatopoeetilist sõnavara (Zotejeva 2007) jm.

\subsection{Väitekirjad ja muud uurimused}

Eesti keele kui teise keele omandamise ning õpetamise alal on Tartu ülikoolis kaitstud viis teadusmagistritööd ja üks doktoriväitekiri ning tehtud veel mõned väiksemad uurimused, mille tulemusi on tutvustatud väitekirjade koosseisu mittekuuluvates artiklites. Seda ei ole just palju ning olukord saab tulevikus muutuda ainult paremaks. Loodetavasti jõuavad enne vanade, nn $4+2$ õppekavade sulgemist kaitsmiseni veel mõned teise keele omandamist käsitlevad teadusmagistritööd.

Valdav osa senistest uurimustest käsitleb kirjalikku õppijakeelt, uuritava keeleainesena on kasutatud nii keeleôppijate loodud terviktekste kui ka uurimuslikel eesmärkidel koostatud testülesannete vastuseid. Kirjaliku keeleainese 
eelistamine on mõistetav, kuna see on suulisega võrreldes kättesaadavam ning materjali kogumine pole nii töömahukas. Peamise uurimismeetodina on kasutatud veaanalüüsi, milles traditsiooniliselt eristatavast viiest etapist -1 ) materjali kogumine, 2) vigade identifitseerimine, 3) vigade klassifitseerimine, 4) vigade põhjuste seletamine, 5) vigade hindamine (Ellis 1985: 51-52) - on eesti keele puhul enim keskendutud neljale esimesele. Reet Pärss (2001) viis Ida-Virumaa vene koolide eesti keele õpetajate hulgas läbi ulatusliku eesti keele testi, mille tulemusi analüüsides jõudis ta tõdemuseni, et riigikeeleõpetajad ise vajaksid süsteemset tänapäeva eesti keele kursust, et oma keeleoskus nõutavale tasemele viia. Olga Pastuhhova (2007) uurimus käsitleb emakeele mõju vene üliõpilaste eesti keele verbirektsioonikasutusele ning on oluline seetõttu, et tegemist on pikiuurimusega. Töös vaadeldakse samade õppijate verbirektsioonitarvitust kahe aasta vältel ning jõutakse tulemusele, et verbirektsioonivead on kivinemisaltid ning emakeele mõjul tehtud vigade arv kaheaastase eesti keele õppe jooksul oluliselt ei vähene. Veaanalüüsi valdkonda kuulub ka Sirje Rammo artikkel vene emakeelega üliõpilaste sõnamoodustusprobleemidest (Rammo 2007). Testülesannete vastuste põhjal tõdeb S. Rammo, et ülikoolis tuletusõpetuse kursuse läbinud tudengitele ei valmista erilisi raskusi kausatiivverbide moodustamine, kuid ise-liiteliste kontinuatiivverbide kasutamine on vene üliõpilastele suureks probleemiks ning onomatopoeetilis-deskriptiivsetele sõnadele tuleks keeleõppes eraldi tähelepanu pöörata (samas).

Veaanalüüsi olemust avatakse pikemalt ka Raili Pooli artikliväitekirja "Eesti keele teise keelena omandamise seaduspärasusi täis- ja osasihitise näitel" (Pool 2007a) sissejuhatavas peatükis ning õppijakeeles esinevad keelevead on suuremal või vähemal määral vaatluse all kõigis väitekirja koosseisu kuuluvates artiklites. Kahes Elle Vaimanniga kahasse kirjutatud artiklis keskendutakse keelevigade klassifitseerimise problemaatikale. Sarnase filoloogilise taustaga kõrgtasemel eesti keelt valdavate teise keele kõnelejate ja eesti keelt emakeelena rääkijate eksamikirjanditest kogutud materjali põhjal jõuavad autorid tulemuseni, et sagedasimad vealiigid (sõnajärje-, sõnastus- ja sõnavalikuvead jm) on mõlemal informandirühmal üldiselt sarnased, kuid eesti rühma töödes esines rohkem interpunktsiooni- ning kokku-lahkukirjutamise 
vigu (Pool ja Vaimann 2005). Samade eesti keele õppijate kaheaastase vahega kirjutatud kirjanditest kogutud keelevigade sagedusjärjestusi analüüsides teevad samad autorid tähelepanekuid kivinemisnähtuste kohta ning leiavad, et kivinemine võib leida aset nii grammatika (nt sõnajärg, täis- ja osasihitise kasutamine, rektsioon) kui ka leksika tasandil, sõltudes siiski tugevasti õppijate individuaalsetest iseärasustest (Pool ja Vaimann 2006). Veaanalüüsiga seondub ka R. Pooli väitekirja koosseisu kuuluv artikkel, mis käsitleb õppijate kirjalikes töödes esinevate keelevigade parandamist eesti ja vene emakeelega õpetajate poolt (Pool 2007b). Artiklis kirjeldatud katse tulemused näitavad, et nii K1- kui ka K2kõnelejatest õpetajad parandavad kindlasti ära otseselt grammatikareeglite rikkumisest tulenevad vead, kuid aktsepteeritakse selliseid eksimusi, kus pole võimalik lähtuda otseselt reeglist, vaid tuleks appi võtta keeletaju (samas). Neli väitekirja artiklit keskenduvad konkreetsemalt täis- ja osasihitise problemaatikale. Õppijate introspektsiooni käsitlev kirjutis sisaldab ka järgmiste artiklite koostamisel vajalikuks osutunud infot selle kohta, kuidas eesti keele õppijad ise täis- ja osasihitise valikut põhjendavad (Pool 2006a). Sihitise vormihomonüümiale keskenduvas artiklis kirjeldatakse õppijakeelest kogutud näiteid, mil pole võimalik üheselt kindlaks teha, millist kahest või ka kolmest vormiliselt kokkulangevast objektikäändest õppija on silmas pidanud ning mida ei saa seetõttu emakeelekõneleja keeletaju järgi liigitada (Pool 2006b). Täis- ja osasihitise omandamise ja markeerituse seoseid analüüsides jõuab R. Pool tulemuseni, et vaadeldud vene emakeelega informandirühma objektikäänete omandatuse hierarhia on partitiiv > genitiiv > nominatiiv ning see langeb kokku eesti keele sihitise käänete süntaktilise markeerituse hierarhiaga (Pool 2007c). Viimane R. Pooli doktoritöö koosseisu kuuluv artikkel annab ülevaate keeleõppijate poolt rakendatavate vältimisstrateegiate olemusest ning kirjeldab täisja osasihitise vältimise võimalusi (Pool 2007d). Väitekirja artiklites analüüsitav õppijakeele ainestik on mitmekesine: kasutatud on vaba kirjaliku ja suulise keelekasutuse materjali, oppijate introspektsiooni ning testülesannete vastuseid. Iga artikkel on iseseisev uurimus ning kõik seitse artiklit kokku moodustavad temaatilise terviku. 
Eesti keele kui teise keele uurijatele on pakkunud huvi ka veaanalüüsi viies, vigade hindamise etapp. Erinevalt traditsioonilisest veaanalüüsist ei vaadelda sel juhul otseselt oppijakeeles esinevaid keelevigu, vaid uuritakse emakeelekõnelejate või teise keele kõnelejate reageeringut keeleõppija vigadele. Eesti keele kohta on seni ilmunud Renate Pajusalu (2004) artikkel keeleõppijate tähendusvigade hindamisest ning Elle Vaimanni (2002) artikkel eri tüüpi vigade hindamisest. R. Pajusalu uurimuses paluti eesti emakeelega üliõpilastel parandada lausetes sisalduvad tähendusvead ning hinnata vigade raskusastet kolmeastmelisel skaalal. Katse tulemused on huvipakkuvad, kuna võimaldavad heita pilku sellele, mis eestlasi teise keele kõnelejate keelekasutuses häirib. Peamiselt tähendusvigu sisaldanud testlausetes hinnati kõige raskemaks vigu, mis on seotud ka lause süntaktilise struktuuriga (Pajusalu 2004: 232). E. Vaimanni läbiviidud testis paluti eesti emakeelega informantidel lausetes sisalduvad vead parandada, kuid mitte nende raskusastet hinnata. Seesugune meetod annab infot selle kohta, mida eestlased teise keele kõnelejate tekstides veaks peavad ja mida mitte, kirjeldades tegelikult ka eestlaste endi keelekasutust. E. Vaimanni uurimuse tulemused näitavad, et eestlased ei märka lausetes väga sageli mitmesuguseid grammatikavigu, eriti segased valdkonnad on rektsioon ja ühildumine (Vaimann 2002). Mõned vigade hindamise uurimused on valminud ka üliõpilaste lõputöödena (Vill 2001, Savkovitš 2008) ning see temaatika vajaks kindlasti tulevikus põhjalikumat käsitlemist.

Suulist õppijakeelt on praeguseks uuritud vähe ning senised uuringud on keskendunud suhtlusstrateegiatele. Teedrajavaks on selle temaatika juures Tiit Hennoste ja Triin Vihalemma artiklid vene noorte ja nende eesti eakaaslaste argivestlustest ja võõrkeele suhtlusstrateegiatest (Hennoste ja Vihalemm 1998, 1999), millele järgnevad uurijad on saanud toetuda. Tiina Kikerpill ja Raili Pool on uurinud soome-ugri üliõpilaste suhtlusstrateegiaid vestluses eesti keelt emakeelena kõnelejatega. Pikiuurimuse esimeses osas kirjeldatakse algajate keeleõppijate strateegiaid, mida iseloomustab koodivahetuslike strateegiate rohkus (Kikerpill ja Pool 2002). Uurimuse teise osa materjal on kogutud aastase vaheaja järel samadelt informantidelt, kelle vestlustes on keeleoskuse paranedes täheldatud mitmesuguseid muutusi: vähenenud on 
koodivahetuslike strateegiate osakaal, suurenenud on edasilükkamisstrateegiate kasutamine ning pealerääkimine (Kikerpill, Pool 2003). Artiklite autorid täheldasid muutusi ka vestluse emakeelekõnelejatest osalejate suhtlusstrateegiates algajatega suheldes oli nende kõnes märgata mitmesuguseid õpetajakõnele iseloomulikke jooni, mis uurimuse hilisemas etapis, kui keeleõppijatest vestluspartnerite keeleoskus oli paranenud, enam ei ilmnenud (Kikerpill ja Pool 2002, 2003). Sarnast temaatikat käsitleb ka Jelena Garuse (2006) uurimus keelekümblusklassi ja eesti õppekeelega kooli vene emakeelega laste eesti keele suhtlusstrateegiatest.

Valminud on ka üksikud eesti keele kui teise keele õpetamisele keskenduvad uurimused. Ingrid Nikopensiuse (Rummo) (2001) magistriväitekiri on esimene ülevaade keeleõppe võimalustest interaktiivse infotehnoloogia võimaluste abil, Riina Reinthali (2004) uurimus annab põhjaliku ülevaate eesti keele olukorrast vene õppekeelega üldhariduskoolides. Uurimishuvi on pakkunud ka eesti keele kui teise keele oskuse mõõtmine (Kikerpill, Türk 2007).

\section{3. Õppevahendid ja õppemetoodiline töö}

Mitu eesti keele (võõrkeelena) osakonnas valminud õppevahendit on saanud alguse praktilisest vajadusest. Varasematel aastatel oli osakonna õppetöös praktilistel eesti keele kursustel praegusest suurem osakaal ning muu õppetöö kõrval viidi läbi ka vene ja inglise keele baasil toimuvaid eesti keele intensiivkursusi. Nendel kursustel kasutatud oppematerjalid on avaldatud kahe vihikuna pealkirja „Eesti keele vestluskursus" all, milles sisalduvad õppetekstid on tõlgitud vene ja inglise keelde (Klaas ja Žurakovskaja 1998a, 1998b). Eesti keele põhikursuste tarbeks on koostatud Raili Pooli õppesõnastik „Eesti keele verbirektsioone” (Pool 1999), grammatikakursuste toetamiseks harjutustekogumikud „Rektsiooniharjutusi eesti keelt teise keelena õppijaile” (Pool 2001) ning „Eesti keele sihitise ja rektsiooni harjutusi” (Pool 2006c). Eesti keele sõnavara loengutel kasutatavaks õppevahendiks on Sirje Rammo „Eesti keele sõnavara harjutusi”" (Rammo 2003). Vene emakeelega õppijatele on Sirje Rammo ja Maarika Terali koostööna valminud eesti keele 
grammatika põhireegleid tutvustav voldik, milles sisalduv keeleline info on esitatud paralleelselt nii eesti kui ka vene keeles (Rammo, Teral 2006). Osakonna õppejõududel on valmimas täiskasvanud algajatele mõeldud eesti keele õppekomplekt (autoriteks Birute Klaas, Sirje Rammo, Maarika Teral ja Mari Allik), mis koosneb õpikust, grammatikaülevaatest ja CD-plaadist tekstide ja kuulamisülesannete salvestistega. Komplekt ilmub 2010. aastal. Lisaks traditsiooniliste õppevahendite koostamisele on osakonnas juba mitu aastat tegeldud ka uudsete ning perspektiivikate veebipõhiste interaktiivsete õppematerjalide loomisega. Selliste materjalide koondamiseks ja laiemale õppijaringile kättesaadavaks muutmiseks arendatakse veebipõhist õpikeskkonda „Eesti keele ja kultuuri kursused" (http://www.ut.ee/keeleweb/flah), kuhu saab lisada eri tüüpi keeleharjutusi ning millest lähtuvad lingid muudele terviklikele veebipõhistele õppematerjalidele. Õpikeskkonda on lisatud nt Socrates Lingua 2 projekti „Welcome!“ (linguistic and cultural introduction module for incoming exchange students (20012003)) raames valminud eesti keele ja kultuuri alased materjalid (koostajad Helina Riisalu, Birute Klaas, Ingrid Rummo ja Maarja Must). Nimetatud veebipõhisest õpikeskkonnast lähtub link ka teise rahvusvahelise Socrates Lingua 2 projekti „ONENESS - On-line less used and less taught language courses“ (2004-2006), vt http://www.oneness.vu.lt/ - raames loodud eesti keele ja kultuuri õppematerjali juurde (koostajad Sirje Rammo ja Maarika Teral). See on mõeldud täiskasvanud algtasemel keeleõppijale, kes soovib ühendada keeleõppe kultuurialase teabe omandamisega. Koostööprojektist ja keelekursuse ülesehitusest saab lähemalt lugeda Maarika Terali ja Sirje Rammo artiklist „Oneness - eesti keele õppematerjalid Internetis" (Teral ja Rammo 2007). Lisaks veebipõhistele õppevahenditele on eesti keele (võõrkeelena) osakonnas välja töötatud ka keeleõppematerjalid CDdel. Rahvusvahelise projekti SMALLLINC (An Interactive Approach to Language and Culture (2001-2004)) raames (vt http://www.linclanguages.net/) töötati välja eesti keele õppematerjalid CDROMidel (koostajad Birute Klaas, Sirje Rammo, Maarika Teral), mis sisaldavad kümmet oppetükki erinevatest eluvaldkondadest, tutvustades eesti keelt ja kultuurikeskkonda. Pikemalt on õppematerjalide ülesehitust käsitletud Sirje Rammo 
ja Maarika Terali artiklis „Eesti keele õppematerjalid CDROMil" (Rammo ja Teral 2004).

Lisaks õppevahendite koostamisele tegeldakse eesti keele (võõrkeelena) osakonnas ka keeleõppe metoodika alaste abimaterjalide väljatöötamisega. Keeleõpetaja metoodikavihikute sarjas on ilmunud Tiina Kikerpilli ja Leelo Kingisepa väljaanne „Keelekeskkond võõrkeeleõppe toetajana” (Kikerpill ja Kingisepp 2001), Tiina Kikerpill on ka vene õppekeelega kutsekoolidele mõeldud erialaõppe ning keeleõppe lõimimise teemalise käsiraamatu autor (Kikerpill ja Sõrmus 2008) ning üks vajaliku käsiraamatu „Keeleoskuse mõõtmine” autoreid (Hausenberg jt 2003).

\section{Kokkuvõte ja perspektiivid}

Ükskõik millise uurimissuuna perspektiivikuse üheks kriteeriumiks on kindlasti sel alal tegutsevate doktorantide olemasolu. Eesti keele kui teise keele õpetamise problemaatikaga seondub mitme Tartu ülikooli doktorandi uurimisteema: Maarika Terali töö on seotud interaktiivsete e-õppevahendite loomise võimalustega, Eva Ingerpuu-Rümmel on alustamas doktoritööd kommunikatiivse keeleõppe võimalustest grammatiliste üksuste õpetamisel ning Leila Kubinyi uurib suhtluskonstruktsioonide omandamist ja õpetamist ning teise keele suhtluspädevuse saavutamist. Valdkonnaga haakub ka Dmitri Kulakovi doktoritöö teema Peipsi-äärsete põliselanike kakskeelsusest. Ainus otseselt eesti keele kui teise keele omandamise uurimisel põhinev väitekiri on valmimas Diana Maislal, kes uurib teise keele kõnelejate ajavormikasutust.

Uurimissuuna arendamist püüavad jätkata eesti keele (võõrkeelena) osakonna õppejõud ja teadustöötajad. Võimalusi on palju, sest tehtud on veel vähe: uurida tuleks eri emakeeltega õppijate eesti keele omandamise universaale ning emakeelest sõltuvaid erijooni, oleks vaja käivitada pikiuurimus, mis võimaldaks uurida omandamise kulgu ning täpsustada kivinemisnähtuste avaldumisviise, väga vähe on seni kogutud ja kasutatud suulise õppijakeele ainest ning põhjalikumat uurimist vajab teise keele kõnelejate ja emakeelekõnelejate suuline suhtlus. Ka õppemetoodilise töö edasiarendamisel on mõttekas tihedamalt siduda tegeliku keeleomandamise uuringud ja õpeta- 
mise metoodika. Siiani on õppijakeele uuringute peamisi eesmärke olnud andmete kogumine õpetamise metoodika parandamiseks ning paremate õppematerjalide loomiseks. Nüüd oleks aeg hakata probleemi ka teise nurga alt vaatama ehk uurima, missuguste metoodikate ja õppevahendite abil eesti keele omandamine tegelikult kõige efektiivsemalt toimub. Õppematerjalide arendamisel võetakse suund interaktiivsete veebipõhiste keeleülesannete väljatöötamisele.

Eesti keele kui teise keele uurimissuuna edasine areng Tartu ülikoolis oleneb suuresti sellest, kas õnnestub juurde kasvatada teemast huvituvaid noori uurijaid. Praeguseni on valdkonnaga tegelemine olnud üksikute entusiastide õlul, kellele uurimisgrupi loomine on lähiaastate tõsiseks väljakutseks.

\author{
Aadress: \\ Raili Pool \\ Eesti keele võõrkeelena osakond \\ Tartu Ülikool \\ Ülikooli 18 \\ 50090 Tartu \\ E-mail: raili.pool@ut.ee
}

\title{
Kirjandus
}

Bendi, Kristi (2004) Paronü̈̈mid ja nende õpetamise ning omandamisega seotud probleemid eesti keeles. Käsikirjaline bakalaureusetöö. Tartu: Tartu Ülikool. Eesti keele (võõrkeelena) osakond.

Borissenko, Olga (2009) Eesti keele õppe motivatsioon Tartu vene óppekeelega koolides. Käsikirjaline magistritöö. Tartu: Tartu Ülikool. Eesti keele (võõrkeelena) osakond.

Borovkova, Natalja (2008) Liitsõnade moodustamisoskuse probleeme vene óppekeelega gümnaasiumis. Käsikirjaline magistritöö. Tartu: Tartu Ülikool. Eesti keele (võõrkeelena) osakond.

Ellis, Rod (1985) Understanding Second Language Acquisition. Oxford University Press.

Garus, Jelena (2006) Keelekümblusrühmas ja eesti rühmas óppivate venekeelsete laste suhtlemisstrateegiatest. Käsikirjaline MA töö. Tartu: Tartu Ülikool. Eesti keele (võõrkeelena) osakond. 
Grudkina, Julia (2002) Eesti keele sõnajärg vene emakeelega õpilaste kirjalikes töödes. Käsikirjaline bakalaureusetöö. Tartu: Tartu Ülikool. Eesti keele (võõrkeelena) osakond.

Hausenberg, Anu-Reet, Tiina Kikerpill, Maia Rõigas ja Ülle Türk (2003) Keeleoskuse mõotmine. Käsiraamat. Tallinn: TEA.

Hennoste, Tiit (2003) „Keelekasutuse uurimine“. Eesti keele uurimise analüüs. Koostanud Mati Erelt. Emakeele Seltsi aastaraamat 48, 217 262. Tallinn: Emakeele Selts.

Hennoste, Tiit ja Triin Vihalemm (1998) „Vene noorte toimetulek spontaanses argivestluses eesti eakaaslastega: sissejuhatus probleemistikku." Mitmekultuuriline Eesti: väljakutse haridusele, 249-276. Toimetanud Marju Lauristin, Silvi Vare, Tiia Pedastsaar ja Marje Pavelson. Tartu.

Hennoste, Tiit ja Triin Vihalemm (1999) „Võõrkeele suhtlusstrateegiad”. Akadeemia 8, 1571-1607.

Kikerpill, Tiina ja Leelo Kingisepp (2001) Keelekeskkond võorkeeleõppe toetajana. Keeleõpetaja metoodikavihik. Tallinn: TEA.

Kikerpill, Tiina ja Raili Pool (2002) „Soome-ugri üliõpilaste eesti keele suhtlusstrateegiad." Emakeel ja teised keeled III, 81-94. Toimetanud Liina Lindström ja Oksana Palikova. (Tartu Ülikooli eesti keele (võõrkeelena) õppetooli toimetised 1.) Tartu: Tartu Ülikooli Kirjastus.

Kikerpill, Tiina ja Raili Pool (2003) „Muutused eesti keelt teise keelena kõnelejate suhtlusstrateegiate kasutuses ühe aasta jooksul". VIRSU. Viro ja suomi: kohdekielet kontrastissa, 50-60. Toimittaneet Pirkko Muikku-Werner ja Hannu Remes. (Lähivertailuja 13.) Joensuu.

Kikerpill, Tiina ja Elle Sõrmus (2008) Erialaõppe ja keeleõppe lõimimisest. Käsiraamat vene õppekeelega kutseõppeasutustele. Tallinn: Integratsiooni Sihtasutus.

Kikerpill, Tiina ja Ülle Türk (2007) „Ametikeele oskuse mõõtmine: tekst ja ülesanne eesti keele kui teise keele kuulamistestis". Eesti Rakenduslingvistika Ühingu aastaraamat 3, 177-191. Toimetanud Helle Metslang, Margit Langemets ja Maria-Maren Sepper. Tallinn: Eesti Keele Sihtasutus.

Klaas, Birute (2003) „Eesti keele õpetamisest ja uurimisest võõrkeelena ja teise keelena Tartu Ülikoolis”. 200 aastat eesti keele ülikooliõpet. Juubelikogumik, 319-348. Koostaja Valve-Liivi Kingisepp, toimetaja Mati Erelt. Tartu.

Klaas, Birute ja Natalja Žurakovskaja (1998a) Eesti keele vestluskursus. Разговорный курс эстонского языка. Tartu.

Klaas, Birute ja Natalja Žurakovskaja (1998b) Eesti keele vestluskursus. Conversational Course in Estonian. Tartu. 
Ljutov, Natalja (2007) Kahe Tartu linna lastepäevakodu muukeelsete laste eesti keele omandamise tase. Käsikirjaline bakalaureusetöö. Tartu: Tartu Ülikool. Eesti keele (võõrkeelena) osakond.

Nikopensius (Rummo), Ingrid (2001) Võõrkeelte osaoskuste õpetamine ja arendamine interaktiivse infotehnoloogia võimalusi kasutades. Käsikirjaline $M A$ töö. Tartu: Tartu Ülikool. Eesti keele (võõrkeelena) osakond.

Orlova, Viktoria (2003) Vene rahvusest üliõpilaste eesti keele objektivigade analüïs. Käsikirjaline bakalaureusetöö. Tartu: Tartu Ülikool. Eesti keele (võõrkeelena) osakond.

Pajusalu, Renate (2004) „Keeleõppija tähendusviga ja selle hindamine”. Toimiv keel II. Töid rakenduslingvistika alalt, 218-235. Toimetanud Maria-Maren Sepper ja Jane Lepasaar. (TPÜ eesti filoloogia osakonna toimetised 3.) Tallinn: TPÜ Kirjastus.

Pastuhhova, Olga (2005) „Interferentsivead vene üliõpilaste suulise ja kirjaliku eesti keele süntaksis”. Teine keel. Uurimusi eesti keele kui teise keele omandamisest, 75-110. Toimetaja Raili Pool. (Tartu ülikooli eesti keele (võõrkeelena) õppetooli toimetised 5.) Tartu: Tartu Ülikooli Kirjastus.

Pastuhhova, Olga (2007) Vene emakeelega üliópilaste eesti keele verbirektsiooni omandamisest. Käsikirjaline MA töö. Tartu: Tartu Ülikool. Eesti keele osakond.

Pool, Raili (1999) Eesti keele verbirektsioone. Tartu: Tartu Ülikooli Kirjastus. Pool, Raili (2001) Rektsiooniharjutusi eesti keelt võõrkeelena õppijaile. Tartu.

Pool, Raili (2006a) „Täis- ja osasihitise kasutamisest eesti keelt teise keelena õppijate pilgu läbi”. Eesti Rakenduslingvistika Ühingu aastaraamat 2, 185-202. Toimetajad Helle Metslang ja Margit Langemets. Tallinn: Eesti Keele Sihtasutus.

Pool, Raili (2006b) „Sihitise vormihomonüümia - keeleuurija probleem, keeleõppija tugi”. Lähivertailuja 17, 85-101. Toimetajad Külvi Pruuli ja Annekatrin Kaivapalu. (Jyväskylä Studies in Humanities 53.) Jyväskylä: Jyväskylän yliopisto.

Pool, Raili (2006c) Eesti keele sihitise ja rektsiooni harjutusi. Tartu: Tartu Ülikooli Kirjastus.

Pool, Raili (2007a) Eesti keele teise keelena omandamise seaduspärasusi täisja osasihitise näitel. (Dissertationes Philologiae Estonicae Universitatis Tartuensis 19.) Tartu: Tartu Ülikooli Kirjastus.

Pool, Raili (2007b) „Keelevigade parandamisest eesti keelt teise keelena õppijate kirjalikes töödes". Emakeel ja teised keeled V, 132-150. Toimetaja Raili Pool. (Tartu Ülikooli eesti keele (võõrkeelena) õppetooli toimetised 6.) Tartu: Tartu Ülikooli Kirjastus. 
Pool, Raili (2007c) „Täis- ja osasihitise omandamise ning markeerituse seosest”. Keel ja Kirjandus 1, 35-50.

Pool, Raili (2007d) „Keeleõppijate vältimisstrateegiatest eesti keele täis- ja osasihitise näitel”. Eesti Rakenduslingvistika Ühingu aastaraamat 3, 235-252. Toimetanud Helle Metslang, Margit Langemets ja MariaMaren Sepper. Tallinn: Eesti Keele Sihtasutus.

Pool, Raili ja Elle Vaimann (2005) „Vead kõrgtasemel eesti keele kõnelejate kirjalikus keelekasutuses". Eesti Rakenduslingvistika Ühingu aastaraamat 1, 115-138. Koostaja Margit Langemets, toimetaja Maria-Maren Sepper. Tallinn: Eesti Keele Sihtasutus.

Pool, Raili ja Elle Vaimann (2006) „Kivinemisnähtusi vene üliõpilaste kirjalikus eesti keeles". Eesti Rakenduslingvistika Ühingu aastaraamat 2, 203-217. Toimetajad Helle Metslang ja Margit Langemets. Tallinn: Eesti Keele Sihtasutus.

Rammo, Sirje (2007) „Eesti keele sõnatuletussüsteemi omandamisega seotud probleeme". Emakeel ja teised keeled V, 175-183. (Tartu Ülikooli eesti keele (võõrkeelena) osakonna toimetised 6.) Toimetaja Raili Pool. Tartu: Tartu Ülikooli Kirjastus.

Rammo, Sirje (2003) Eesti keele sõnavara harjutusi. (Tartu Ülikooli eesti keele (võõrkeelena) õppetooli toimetised 2.) Tartu: Tartu Ülikooli Kirjastus.

Rammo, Sirje ja Maarika Teral (2004) „Eesti keele õppematerjalid CDROMil". Emakeel ja teised keeled IV, 156-163. (Tartu ülikooli eesti keele (võõrkeelena) osakonna toimetised 3.) Toimetanud Birute Klaas ja Silvi Tenjes. Tartu: Tartu Ülikooli Kirjastus.

Rammo, Sirje ja Maarika Teral (2006) Eesti keele grammatika põhireeglid. Voldik. Tartu: Atlex.

Pärss, Reet (2001) Kohtla-Järve, Jõhvi ja Sillamäe vene õppekeelega koolide riigikeeleõpetajate eesti keele oskusest. Käsikirjaline MA töö. Tartu: Tartu Ülikool. Eesti keele (võõrkeelena) osakond.

Ratassepp, Maria (2005) „Vene abiturientide vead eesti keele verbirektsioonis". Teine keel. Uurimusi eesti keele kui teise keele omandamisest, 111-134. Toimetaja Raili Pool. (Tartu ülikooli eesti keele (võõrkeelena) õppetooli toimetised 5.) Tartu: Tartu Ülikooli Kirjastus.

Reinthal, Riina (2004) Eesti keel Eesti vene õppekeelega üldhariduskoolis. Käsikirjaline $M A$ töö. Tartu: Tartu Ülikool. Eesti keele (võõrkeelena) osakond.

Savkovitš, Anastassia (2008) Emakeelekõnelejate hinnangud mitte-eestlaste vigadele kirjalikus keelekasutuses. Käsikirjaline magistritöö. Tartu: Tartu Ülikool. Eesti keele (võõrkeelena) osakond. 
Šarapova, Julia (2005) „Eesti keele isikulise tegumoe minevikuaegade õppimine ja omandamine". Teine keel. Uurimusi eesti keele kui teise keele omandamisest, 135-172. Toimetaja Raili Pool. (Tartu ülikooli eesti keele (võõrkeelena) õppetooli toimetised 5.) Tartu: Tartu Ülikooli Kirjastus,.

Zotejeva, Kristina (2007) Vene-eesti vahekeele onomatopoeetiline sõnavara. Käsikirjaline magistritöö. Tartu: Tartu Ülikool.Eesti keele (võõrkeelena) osakond.

Teral, Maarika ja Sirje Rammo (2007) „ONENESS - eesti keele õppematerjalid Internetis". Emakeel ja teised keeled V, 256-263. (Tartu ülikooli eesti keele (võorrkeelena) õppetooli toimetised 6.) Toimetaja Raili Pool. Tartu: Tartu Ülikooli Kirjastus.

Titova, Irina (2003) Modaalset tähendust sisaldavate verbide jaksama, oskama, saama, suutma, tohtima ja võima kasutamine vene gümnaasiumide ópilaste poolt. Käsikirjaline bakalaureusetöö. Tartu: Tartu Ülikool. Eesti keele (võõrkeelena) osakond.

Tšerednikova, Jelena (2002) Ühildumisvead vene üliõpilaste kirjalikes töödes. Käsikirjaline bakalaureusetöö. Tartu: Tartu Ülikool. Eesti keele (võõrkeelena) osakond.

Vaimann, Elle (2002) „Mis on eesti keeles viga?” Emakeel ja teised keeled III, 250-257. Toimetanud Liina Lindström ja Oksana Palikova. (Tartu Ülikooli eesti keele (võõrkeelena) õppetooli toimetised 1.) Tartu: Tartu Ülikooli Kirjastus.

Vill, Taimi (2001) Viga eesti keeles eesti kooli ópilase hinnangul. Käsikirjaline bakalaureusetöö. Tartu: Tartu Ülikool. Eesti keele osakond.

Vlassova, Olga (2002) Muutumisverbide jääma, saama, minema ja muutuma kasutamine vene ofpilaste poolt. Käsikirjaline bakalaureusetöö. Tartu: Tartu Ülikool. Eesti keele (võõrkeelena) osakond. 
Eesti keel teise keelena Tartu Ülikoolis 16

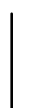

